\title{
Drug Delivery System for Controlled Cancer Therapy Using Physico- Chemically Stabilized Bioconjugated Gold Nanoparticles Synthesized from Marine Macroalgae, Padina Gymnospora
}

\author{
Manoj Singh ${ }^{1,3}$, Manish Kumar², S Manikandan' ${ }^{1}$, N Chandrasekaran $^{3}$, Amitava Mukherjee $^{3}$ and AK Kumaraguru $^{1}$ \\ ${ }^{1}$ Department of Marine and Coastal Studies, Madurai Kamaraj University, Tamilnadu, India \\ ${ }^{2}$ Advanced Instrumentation Research Facility, Jawaharlal Nehru University, New Delhi, India \\ ${ }^{3}$ Centre for Nanobiotechnology, VIT University, Tamilnadu, India
}

\begin{abstract}
Gold nanoparticles (AuNPs) have always been considered as superior tools for biosystem applications owing to their characteristic optical properties in form of surface plasmon resonance and amperometric properties with very low or no immediate toxicity. Biosystem application based tools have been designed based on many studies with gold nanoparticles but the reduction of bulk material to nanosized particle in conjugation with biomolecules in a physicochemical environment is an area requiring deeper investigation. In the present study complementary high resolution imaging techniques on different length scale are applied to elucidate morphology of gold nanoparticles. The biomolecules involved in conjugation and reduction were further characterized. The impact of macroalgae broth concentration on formation of AuNPs (8-21 nm) were further studied to determine the functional and molecular mechanism of cell death on Liver cancer (HepG2) cell line and Lung cancer (A549) cell line. We report AuNPs-induced death response in human carcinoma liver cell line HepG2 in contrast to lung cancer cell line which remained little affected. The induction specificity for death response in lung cells clarifies that AuNPs do not universally target all cell types. Altered DNA fragmentation and cell staining in different cancer cell suggests a potential for in vivo applications of gold nanomaterials and demands the need of the time for studies evaluating the interactions of nanomaterials with biomolecules and cellular components for controlled cancer therapy.
\end{abstract}

Keywords: Cellular effects; Physico-chemical parameter; Drug delivery system; Amperometric; Gold nanoparticle

\section{Introduction}

Nanoscale materials hold great promise for both industrial and biomedical applications. Since, cancer is observed as the most dangerous class of disease categorized by uncontrolled cell growth [1]. Cancer is the third leading cause of death (after heart disease and stroke) in developed countries and the second leading cause of death (after heart disease) in the United States (see http://www.cdc.gov). Lung, stomach, liver, colon and breast tumour are the main types of tumors that lead to total death worldwide. Studies have shown that there were 10 million new cases, 6 million deaths, and 22 million people living with cancer worldwide in the year 2000 [2]. These numbers represent an increase of about $22 \%$ in incidence and mortality from that of the year 1990. It is projected that the number of new cases of all cancers worldwide will be 12.3 and 15.4 million in the year 2010 and 2020, respectively [3]. In many types of cancer, we are yet to find a satisfactory medicine or carrier of medicine as in case of drug delivery to be used as a satisfactory chemotherapeutic agent [4].

Thus, nanotechnology, an interdisciplinary research field comprising chemistry, engineering, biology, and medicine, has great potential for early detection, accurate diagnosis, and tailored treatment of cancer [1]. Toxicological studies suggest that nanoparticles may cause adverse health effects, but the fundamental cause-effect relationships are ill defined. Thus, the interaction of nanoparticles with biological systems including living cells has become one of the most urgent areas of collaborative research in materials science and biology [5]. The most interesting properties of nanoparticles, that is, the quantum size effect or surface-induced effects, result from their minute size. Nanoparticles are of similar size to typical cellular components and proteins, and thus may bypass natural mechanical barriers, possibly leading to adverse tissue reaction. These nanoparticles can offer unprecedented interactions with biomolecules both on the surface and inside the body cells, which may bring revolution in cancer diagnosis and treatment [6]. The well-studied nanoparticles for targeting cancer include paramagnetic nanoparticles [7], liposome [8] and gold nanoparticles [9]. In addition, AuNPs also serve as specialized microscopic probes to study cancer cells, because AuNPs selectively accumulate in tumor cells, showing bright scattering [10].

Thus, there is an increasing need to develop high-yield, low cost effective, nontoxic and environmentally benign procedures for synthesis of metallic gold nanoparticles. Therefore, the biological approach for synthesis of nanoparticles becomes important. The potential of plants as biological materials for the synthesis of nanoparticles is yet to be fully explored. The importance of seaweeds as a marine resource for biomimetic synthesis of metallic nanoparticle may be emphasized due to the increasing demand for medicinal products like antibiotics such as antibacterial, antifungal, antiviral and antitumour activity with enhanced properties. From the above experiments it is also known that green synthesis showed high stability under the preparatory conditions. These results prompted us to start a series of cell-based experiments, in which the bioconjugated gold nanoparticles might show differential permeability for human cancer cells.

${ }^{*}$ Corresponding author: Manoj Singh, Department of Marine and Coastal Studies Madurai Kamaraj University, Madurai, Tamil Nadu, India, Tel: 09994798962, E-mail: marinenanomed@gmail.com or Manoj.Singh@vit.ac.in

Received December 16, 2013; Accepted February 10, 2014; Published February 14,2014

Citation: Singh M, Kumar M, Manikandan S, Chandrasekaran N, Mukherjee A, et al. (2014) Drug Delivery System for Controlled Cancer Therapy Using Physico-Chemically Stabilized Bioconjugated Gold Nanoparticles Synthesized from Marine Macroalgae, Padina Gymnospora. J Nanomed Nanotechol S5:009. doi:10.4172/2157-7439.S5-009

Copyright: ( 2014 Singh M, et al. This is an open-access article distributed under the terms of the Creative Commons Attribution License, which permits unrestricted use, distribution, and reproduction in any medium, provided the original author and source are credited. 


\section{Material and Methods}

\section{Bioreduction and surface characterization gold nanoparticles (AuNPs)}

Bioreduction of bulk gold chloride to synthesize AuNPs was conducted with $10^{-3} \mathrm{M}$ trivalent aurum solutions with different broth concentration $(1,3,5,10$ and 20\%) of brown seaweed (Padina gymnospora) leaf extract (SLE). The effect of different leaf broth concentration was investigated for the optimum and controlled synthesis of gold nanoparticles. The optimum $\mathrm{pH}$ of 9.5 and $75^{\circ} \mathrm{C}$ temperature of the reaction medium was kept constant and the absorbance values of broth solutions were measured between 300-700 $\mathrm{nm}$ spectrophotometrically. The process of separation of biological debris from nanoparticles was established following centrifugation and redispersion of broth solution in sterile deionized water thrice at $12000 \mathrm{rpm}$ for 20 minutes to obtain better separation of entities from the nanoparticles. The pellet obtained at final centrifugation was frozen at $-70{ }^{\circ} \mathrm{C}$ to remove water residue and lyophilized using Lyophillizer (Micro Modulyo 230 freeze dryer, Thermo Electron Corporation, India). The lyophilized nanoparticle samples were stored at $4^{\circ} \mathrm{C}$ [11]. HRTEM (JEOL TEM-2100F) \& Energy dispersive X-ray analysis (EDX) was applied to determine the surface morphology, size pattern and the chemical composition of the AuNPs by drop coating of dried gold nano powder on to carbon film at an operating voltage of $200 \mathrm{kV}$.

\section{Cell culture and cytotoxicity assays}

Two cell lines, Human hepatocellular liver carcinoma; HepG2 and Human lung adenocarcinoma epithelial cell line; A549 were used in this study. All cells were cultured in Dulbecco's modified Eagle medium (DMEM) at $37^{\circ} \mathrm{C}$ in water-saturated air supplemented with $5 \% \mathrm{CO}_{2}$. Culture media was changed and passaged once in three days. Cell numbers were estimated using a cell counter (Schaerfe cell counting system, Germany). Passaging of immortalized cell lines was further possible but the risk of genotypic changes increases rapidly [12]. Cell cultivation and experimental incubation were performed in a cell incubator for the formation of confluent monolayer. Cells were plated in 96 -well microtiter plates at initial densities of $1 \times 10^{5}$ cells $/ \mathrm{ml}$ per well. The monolayer of cells in the plate was exposed to $1 \mathrm{~mL}$ of MEM medium containing different concentration of biofunctionalizedAuNPs $(5,15,30,60,120 \mathrm{nM} /$ well). After $48 \mathrm{~h}$ of culture, $200 \mu \mathrm{l}$ of $0.5 \%$ MTT $(5 \mathrm{mg} / \mathrm{ml})$ solution and $1 \mathrm{ml}$ of DMSO was added per well and left for 4 hours. Cell growth was tested by the colorimetric MTT assay, which measures the conversion of the yellowish water-soluble tetrazolium salt to a water-insoluble purple formazan product within viable breathing cells as a proxy of cell number and viability. The waterinsoluble formazan was dissolved in $1 \mathrm{~mL}$ isopropyl alcohol with the specified percentage of $\mathrm{HCl}$, and their absorbance values were measured using a spectrophotometer (Analytik Jena, Spekol 1200). Absorption of the samples was measured using spectrophotometer at $584 \mathrm{~nm}$. The amount of formazan produced is directly proportional to the number of living cells in the well.

\section{Molecular mechanism of cell death: DNA fragmentation}

Agarose gel electrophoresis, a technique widely used for DNA damage analysis in cells undergoing apoptosis. Such phenomenon to detect apoptosis via the DNA laddering assay was described for the first time [13]. About $1 \mathrm{~mL}$ cell suspension $\left(10^{5} \mathrm{cells} / \mathrm{ml}\right)$ was seeded into each culture well and incubated at $37^{\circ} \mathrm{C}$ for $48 \mathrm{~h}$ in $5 \% \mathrm{CO}_{2}$ for the formation of confluent monolayer. The monolayer of cells in the culture dishes were gently washed twice with MEM and then the monolayer of cells in the dishes were exposed to $1 \mathrm{ml}$ of MEM medium containing defined different concentration of the gold nanoparticles. Control cells were treated with $0.25 \%$ DMSO. After $48 \mathrm{~h}$ of culture, cellular DNA was extracted by proteinase $\mathrm{K}$ digestion [14] from treated and untreated tumour cells. $1 \times 10^{6}$ cells were re-suspended in $1 \mathrm{ml}$ of cell lysis buffer containing $50 \mathrm{mM}$ Tris $\mathrm{HCl}(\mathrm{pH} 8.0), 10 \mathrm{mM}$ ethylenediaminetetraacetic acid (EDTA), $0.1 \mathrm{M} \mathrm{NaCl}$, and $0.5 \%$ sodium dodecyl sulfate. The lysate was incubated with $0.25 \mathrm{mg} / \mathrm{ml} \mathrm{RNase} \mathrm{A} \mathrm{at}$ $37^{\circ} \mathrm{C}$ for 30 minutes, and then with $0.2 \mathrm{mg} / \mathrm{mL}$ proteinase $\mathrm{K}$ at $50^{\circ} \mathrm{C}$ overnight. DNA was extracted by phenol: chloroform: isoamyl alcohol (25: 24: 1) mixture, precipitated in ethanol. DNA electrophoresis was performed in a $1 \%$ agarose gel containing ethidium bromide $(0.6 \mu \mathrm{g} /$ $\mathrm{ml}$ ) at $70 \mathrm{~V}$, and the DNA fragments were visualized and photographed under a UV transilluminator.

\section{Morphological changes of apoptosis}

Cells undergoing apoptosis display typical condensed morphology, namely cell shrinkage, chromatin condensation and nuclear fragmentation. Dramatic changes occur within the nucleus during apoptotic death. In addition, patches of localised partially condensed chromatin were found abutted along the inner part of the nuclear membrane. Chromatin condensation, nuclear shrinkage and formation of apoptotic bodies can easily be observed under confocal laser scanning microscopy, after appropriate staining of nuclei with DNA-specific fluorochromes. V-FITC Kit was used for detection and discrimination of apoptotic, necrotic and dead cells [15], chromatin condensation was performed by Hoechst staining [16] while confirmation of apoptosis was achieved using Acridine orange Staining [17].

\section{Statistical analysis}

Lethal concentration dose for growth inhibition were derived using Probit software (EMSL-Cincinnati) and graphs were computed using Graph Pad Prism and Origin Pro software.

\section{Results and Discussion}

The light absorption pattern of different macroalgae biomass concentration with $1 \mathrm{mM} \mathrm{HAuCl}$ solution was kinetically monitored with the help of UV-Vis measurement at regular time interval for formation of $\mathrm{Au}$ nanoparticles (Figure 1). The presence of SPR peak between 500-550 $\mathrm{nm}$ for each broth concentration clearly suggests the formation of gold nanoparticles, which is the characteristic of gold nanoparticles in solution. The increase in absorbance was seen as a function of reaction time. The most stable peak was observed at $544 \mathrm{~nm}$ for macroalgae $P$. gymnospora at $5 \mathrm{~g}$ aqueous leaf extract. Flat gold nanoparticles absorb the wavelength in the NIR region of the electromagnetic spectrum, which corresponds to the longitudinal surface plasmon absorption [18]. The stable synthesis of gold nanoparticle with narrow size distribution was obtained which was further confirmed through Transmission electron microscopy.

\section{Effect of broth concentrations}

The gold nanoparticle synthesized from $1 \mathrm{mM}$ solution of $\mathrm{HAuCl}_{4}$ and 5\% aqueous leaves extract of Padina gymnospora at constant temperature $\left(75^{\circ} \mathrm{C}\right)$ and $\mathrm{pH}(9.5)$ was further investigated for the possibility of controlling the particle size and shape by changing the composition of the reaction mixture. It was found that rate of synthesis wasn't realized at low macrolagae concentrations. Probably, reductant ions couldn't be high enough to reduce gold ions [19]. Au nanoparticles of different sizes ( 8 to $21 \mathrm{~nm}$ ) were obtained at different concentration of macroalga $(1,3,5,10$ and $20 \%)$ broth by keeping control of other 
Citation: Singh M, Kumar M, Manikandan S, Chandrasekaran N, Mukherjee A, et al. (2014) Drug Delivery System for Controlled Cancer Therapy Using Physico-Chemically Stabilized Bioconjugated Gold Nanoparticles Synthesized from Marine Macroalgae, Padina Gymnospora. J Nanomed Nanotechol S5:009. doi:10.4172/2157-7439.S5-009

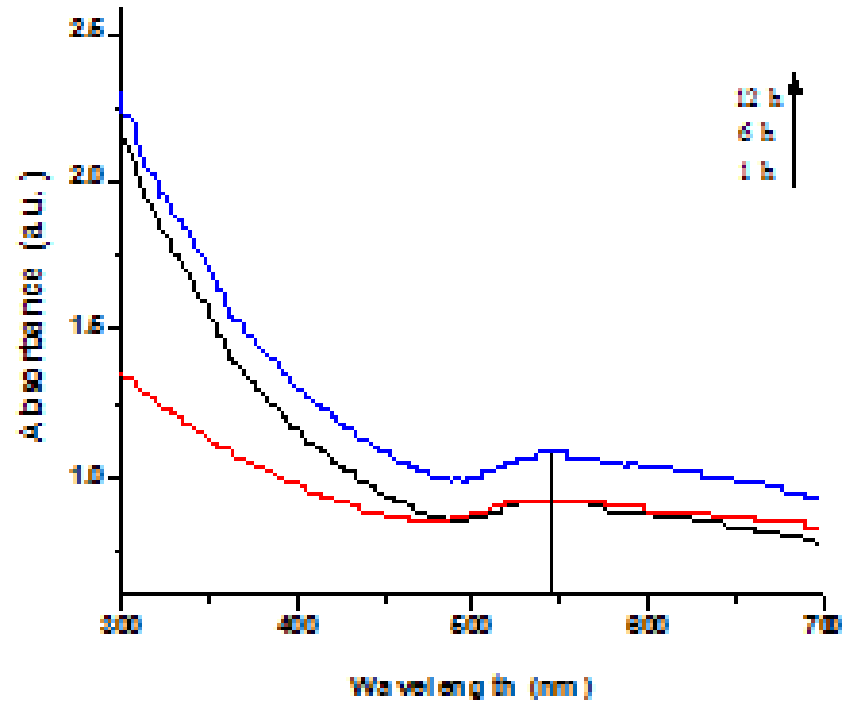

Figure 1: UV-Vis spectra of gold nanoparticles recorded after the reaction of 1 $\mathrm{mM} \mathrm{HAuCl} 4$ solution with $5 \%$ aqueous leaves extract of Padina gymnospora for $12 \mathrm{~h}$

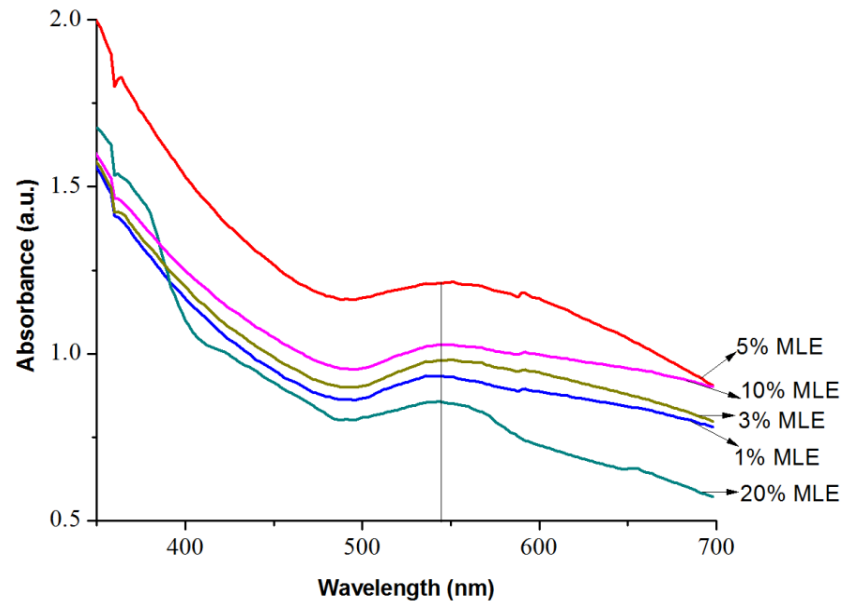

Figure 2: Effect of Macroalgae Leaf Extract (MLE) concentration on gold nanoparticle synthesis under controlled physico-chemical conditions.

physico-chemical parameters (Figure 2). The statements of size used in the following relate to the diameter of the gold core. The low concentration of macroalgae biomass with $\mathrm{HAuCl}_{4}$ led to the formation of increased absorbance. As soon as the broth concentration was increased beyond $20 \%$, the solution started forming aggregates resulting in poor synthesis of AuNPs. From the result, it was concluded that the optimum absorbance occurred at $5 \%$ of macroalgae biomass. The results were similar with Shipway et al. [20] who used sodium citrate to reduce gold chloride for gold nanoparticle synthesis and he concluded that amount of reductant (sodium citrate) is an important parameter for controlling size of the nanoparticle.

The bio-mimetically synthesized AuNPs was purified. The particle size and shape was established changing the composition of the reaction mixture. Figure 3A-3C showed the TEM images of the gold nanoparticles synthesized using different Padina gymnospora leaf broth concentrations (A: $1 \%, \mathrm{~B}: 5 \%$, and C: $10 \%$ ) with $1 \mathrm{mM} \mathrm{HAuCl}_{4}$ at $75^{\circ} \mathrm{C}$.
The particle size was observed to decrease with an increase in the leaf broth concentration. The optimum concentration of macroalgae leaf extract reacting with $\mathrm{HAuCl}_{4}$ led to the formation of spherical nanoparticles with diameter ranging from 8 to $21 \mathrm{~nm}$ (Figure 3D), while the large quantities of mixture nanoparticles were formed on increasing the concentration of the Padina gymnospora leaf extract (Figure 3C). Large quantities of small size nanoparticle with the average diameter of $13 \mathrm{~nm}$ were formed. The high-resolution TEM (HRTEM) images displayed clear lattice fringes on the particle surfaces. Selected area electron diffraction pattern (SAED) of a single spherical particle confirmed the single crystalline nature of gold nanoparticles with the fcc phase. Scherrer ring pattern corresponding to ( $\left.\begin{array}{lll}1 & 1 & 1\end{array}\right),\left(\begin{array}{lll}2 & 0 & 0\end{array}\right)$ and $\left(\begin{array}{lll}2 & 2 & 0\end{array}\right)$ planes of the fcc crystalline lattice of gold was observed for each sample (Figure 3E). Similar changes in the shapes and size were observed on phyllanthin assisted gold nanoparticle biosynthesis [19]. The use of a low concentration of the extract reacting with gold chloride led to the formation of hexagonal or triangular gold nanoparticles, while the shape of the nanoparticles changed to spherical on increasing the concentration of the macroalgae leaves extract. Song et al. [21] has recently reported that control of the shape and size of metallic nanoparticles is very much required to enable the tuning of
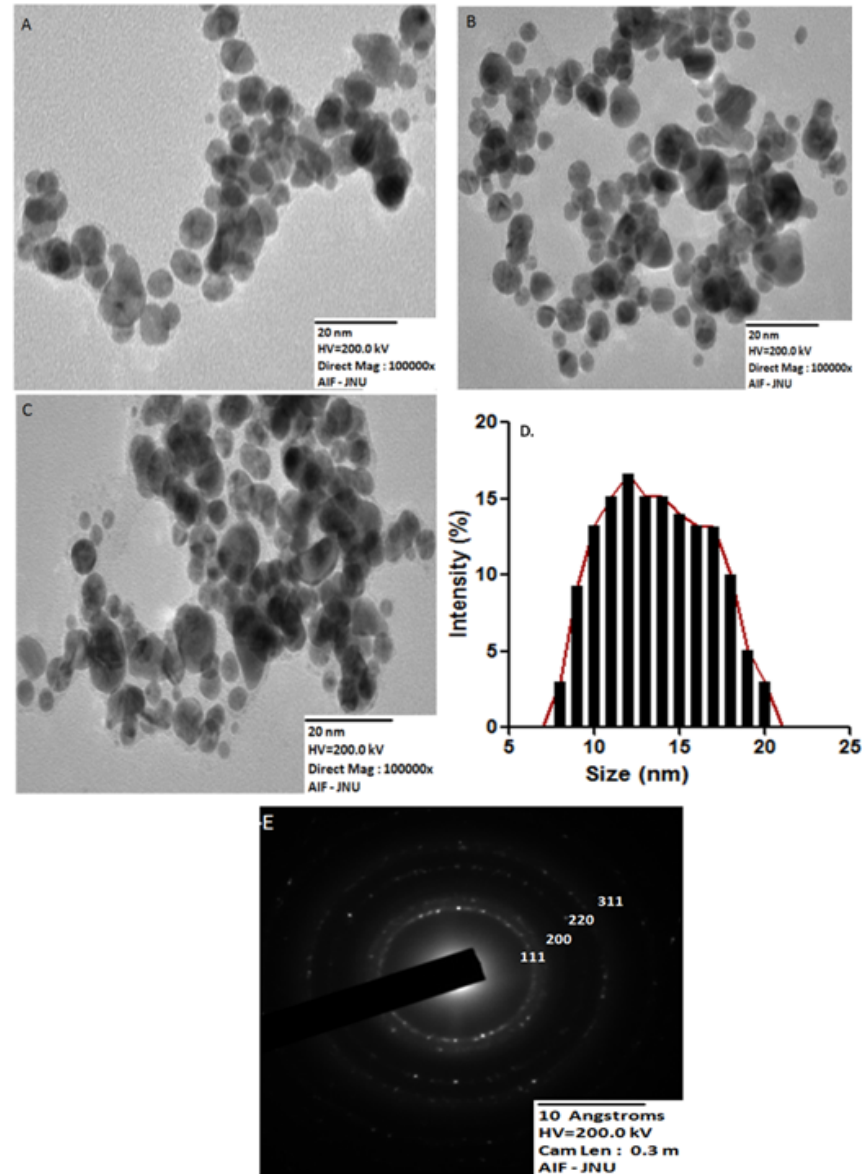

Figure 3: (A) TEM micrograph recorded from a drop-coated film of gold aqueous solution formed by the reaction of $1 \mathrm{mM} \mathrm{HAuCl} 4$ with $1 \%$ Padina gymnospora leaf broth at $\mathrm{pH} 9.5$, (B) at $5 \%$ leaf broth concentration (C) $10 \%$ $\%$ leaf broth concentration. The scale bar corresponds to $20 \mathrm{~nm}$, (D) Gold nanoparticles size distribution histogram, (E) Selected area of electron diffraction pattern recorded from one of the gold nanoparticles. The diffraction rings have been indexed with reference to fcc gold. 
Citation: Singh M, Kumar M, Manikandan S, Chandrasekaran N, Mukherjee A, et al. (2014) Drug Delivery System for Controlled Cancer Therapy Using Physico-Chemically Stabilized Bioconjugated Gold Nanoparticles Synthesized from Marine Macroalgae, Padina Gymnospora. J Nanomed Nanotechol S5:009. doi:10.4172/2157-7439.S5-009

Page 4 of 7

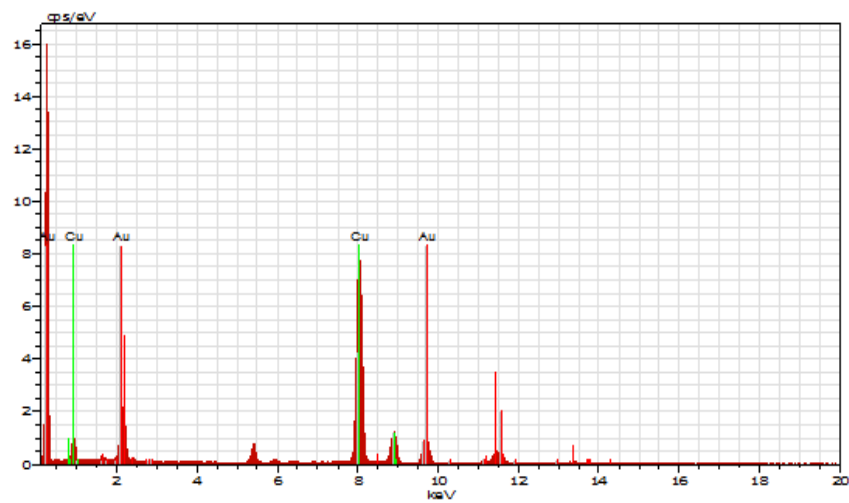

Figure 4: EDS spectral analysis of gold clusters marked with arrows.

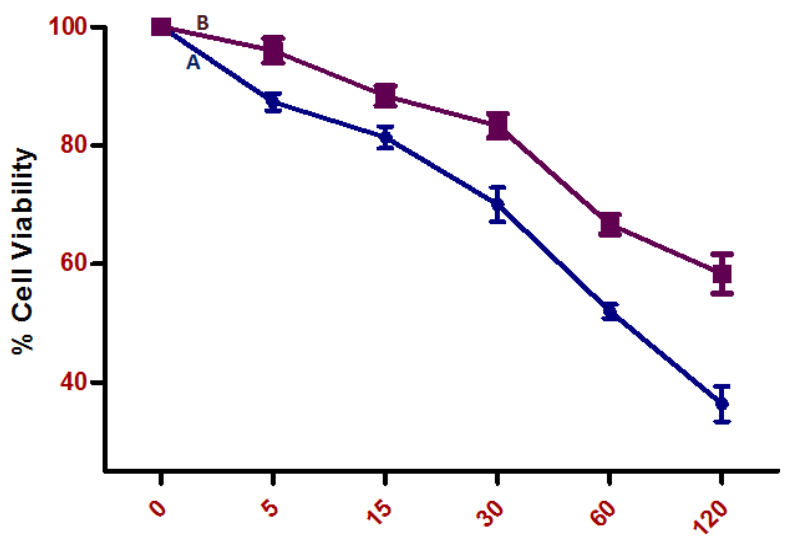

AuNPs Concentration ( $\mathrm{nM}$ )

Figure 5: MTT assay: Cell viability assay by MTT shows reduction in viability with variable concentrations of AuNPs-treated (A) Hep-G2 and (B) A549 cancer cells represented by bar diagram.

their optical, electronic, magnetic and catalytic properties. EDS profile (Figure 4) showed a strong gold signal along with copper because of the copper grid base used for the analysis [22]. We propose that the main biomolecules (fucoxanthin or flavonoids) with an intense broad band absorbance at $3,439 \mathrm{~cm}^{-1}$ was responsible for the reduction of Aurochloric acid to AuNPs as confirmed from FTIR analysis, from our earlier report [23] and was also similar in case of plant-mediated silver nanoparticles [24]. Having confirmed from characterization, the AuNPs synthesized at $5 \%$ of macroalgae biomass with diameter ranging from 8 to $21 \mathrm{~nm}$ was opted for cell cytotoxicity assay.

Having established cultured characteristics on growth for the reporter cell lines, the cells were treated with bioconjugated $\mathrm{Au}$ nanoparticles for up to $48 \mathrm{~h}$ to observe the effect of toxicity. Given the strong reaction of cells to Au nanoparticles illustrated in Figure 5 , this incubation time should reliably detect even low or slow-acting toxicity and vice versa. We performed toxicity tests during both the logarithmic and stationary phases of cell growth following the different concentration of the Au nanoparticles. The Au clusters proved highly toxic in this assay. Notably, at higher AuNPs concentration there was an asymmetric accumulation of AuNPs in the periphery outside the cell nucleus of the HepG2 cells. The results clearly indicated the aggregation of particles inside the cell cytoplasm of liver cancer cell with an IC50 value of about $82.91 \mathrm{nM}$ induced $50 \%$ reduction in cell viability in comparison to lung cancer cell at $144.16 \mathrm{nM}$ concentration (Figure 5). Figure $6 \mathrm{~A}$ and $\mathrm{B}$ demonstrates the cellular morphology change in the HepG2 cell line along with the A549cell line. The phase contrast microscopic images clearly showed that the morphology changes in A549cell line were less significant. The extent of roundedness of the cell; one of the characteristics of stressed cells was measured upon treatment with gold nanoparticles.

Taken together these results suggest a stringent size dependency of the cytotoxicity of nanoscopic gold clusters. Thus the synthesized nanoparticles were found to be potently cytotoxic agent against HepG2 cell lines and mildly cytotoxic against A549 cell lines. However, further study is needed to understand the exact mechanism of anticancer activity of bio-functional gold nanoparticle. Algal pigments, such as fucoxanthins, a kind of carotenoids rich in hydroxyl groups very abundant in polysaccharides of the algal cellwall could have been adsorbed on the surface can stimulate or suppress the immune system due to the presence of $-\mathrm{OH}$ groups. Presence of such phenolic moieties may be assumed to have synergic effect for the antiproliferative activities of these bio-adsorbed metal nanoparticles [25]. The other reason of anti-proliferative activity may be due to anisotropic nanoparticle used in this study [26]. These shape-dependent properties of AuNPs have different behaviour and make them suitable for therapeutic utilization [27,28]. AuNPs of certain non-regular shapes can readily be adsorbed to the surfaces of the biomolecules which show higher surface plasmon resonance and will have a greater contrast effect than those of photothermal dyes that are used regularly in detection of cancer cells [29].

\section{DNA fragmentation}

The cellular metabolic activity seemed affected by the AuNPs, thus, the possibility of apoptosis induction by the nanoparticles was assessed.

A.
Control HepG2 cell

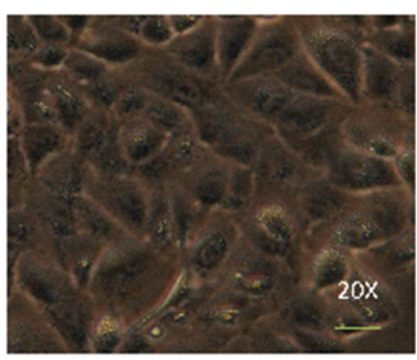

B.

Control A549 cell

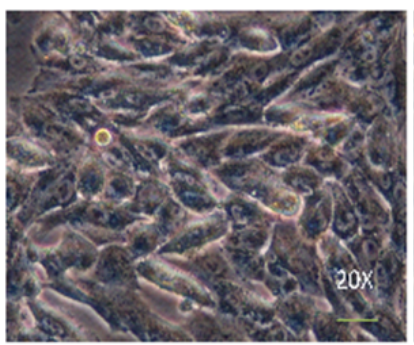

Treated HepG2 cell

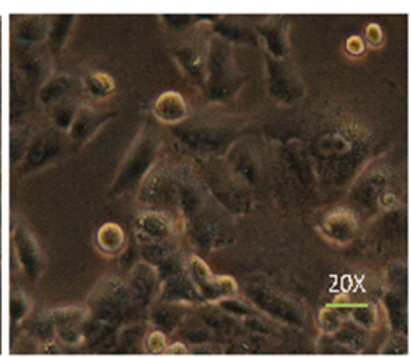

Treated A549 cell

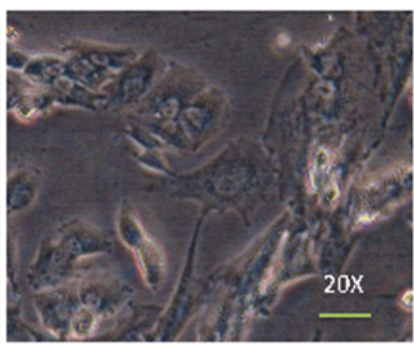

Figure 6: AuNPs induced cellular morphology change in cell lines. (A) Phase contrast images showing cellular morphologies of HepG2 cell lines and (B) A549 cell lines after treatment for 48 hours in the presence and absence of AuNPs. 

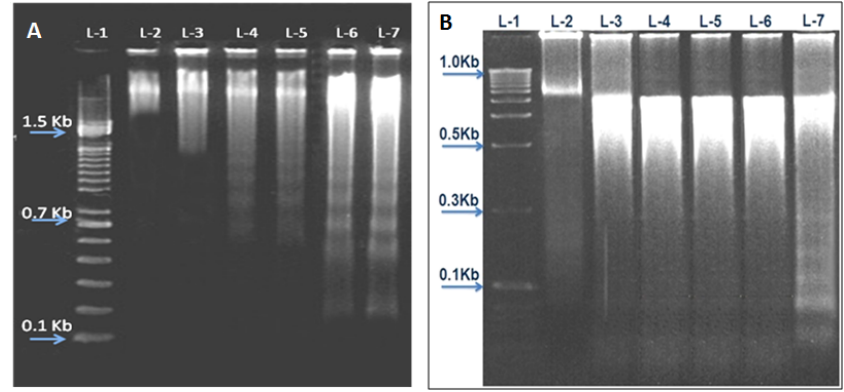

Figure 7: (A) DNA fragmentation assay in HepG2 cancer cells Lane 1 (1.5 kb ladder), Lane 2 (Control) and Lane 3-7 (treated with different concentration of gold nanoparticles). (B) A549 cancer cell line: Lane 1 (1.0 kb molecular marker), Lane 2 (Control) and Lane L3-L7 (treated with different concentration of gold nanoparticles).
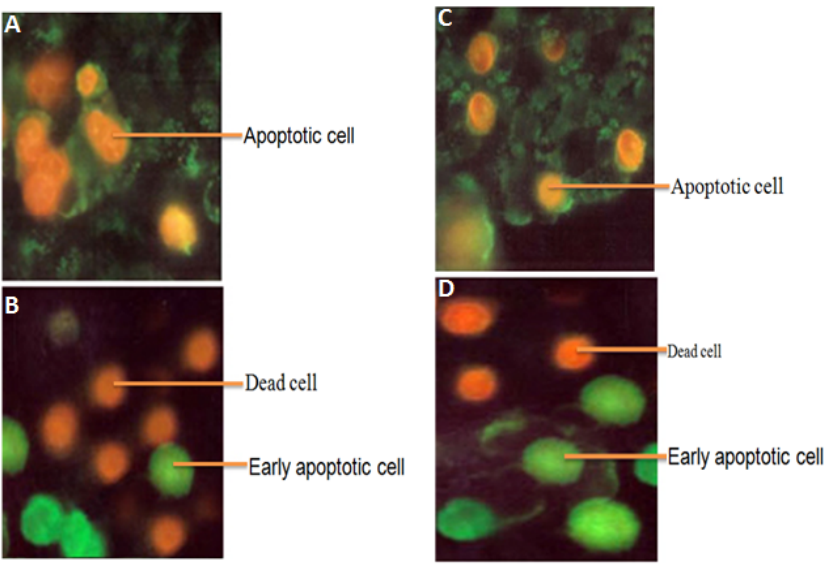

Figure 8: Annexin-V FITC assay: (A) Control HepG2 cell, (B) AuNPs induced apoptosis morphology in HepG2 cancer cells (C) Control A549 cell, (D) AuNPs induced apoptosis morphology in A549 cancer cells.

DNA fragmentation was performed for the tumour cells treated with purified gold nanoparticle and it was determined by visualization of DNA laddering on agarose gel electrophoresis. DNA Fragmentation of the HepG2 cells treated with different concentrations such as 79, 80, 81, 82 and $83 \mathrm{nM}$ (Lane L3, L4, L5, L6 and L7) was performed. DNA ladders of the corresponding treated samples confirmed apoptosis (Figure 7A) and showed that the AuNPs-treated Hep G2 cells exhibited extensive double strand breaks, thereby yielding a higher ladder appearance (Lane 6), while the DNA of control HepG2 cells exhibited minimum breakage (Lane 2). The $1 \mathrm{~kb}$ ladder (Lane 1) was used to find the molecular weight of cleaved DNA fragments.

DNA Fragmentation of the A549 cells treated with different concentrations such as $140,141,142,143$ and $144 \mathrm{nM}$ in Lanes L3, L4, L5, L6 and L7 respectively was performed (Figure 7B), and Lane L3 to L5 showed weak ladder pattern of DNA. DNA ladders of the corresponding treated samples confirmed apoptosis. Fragmented DNA showed a ladder-like pattern of Lane L1 that was the molecular marker while lane L2 was the negative control (untreated cells). Lane L7 showed high ladder pattern of DNA in A549 cells at concentration of $144 \mathrm{nM}$. These changes in DNA represent the biochemical changes involved in the fragmentation of chromosomes into nucleosome units [30]. Fragmented DNA during apoptosis appears as a series of bands, which are described as "DNA ladders" on agarose gels, representing formation of oligonucleosomes with the characteristics of apoptosis [31]. The results of the present study showed, oligonucleosomal DNA laddering in the HepG2 and A549 tumour cells. The laddering pattern resulted in HepG2 and A549 tumour cells producing high molecular weight DNA fragments. This production of megabase-sized DNA fragments is reported to be associated with the detachment of cells from the monolayer and decreased cell volume that does not disturb membrane integrity [32].

\section{Morphological changes of apoptosis}

Biofunctionalized bioconjugate gold nanoparticles treatment on HepG2 and A549 cells were stained with Annexin-V and morphological changes were immediately observed under fluorescence microscopy. HepG2 cell treated with $82.91 \mathrm{nM}$ and A549 cell treated with $144.16 \mathrm{nM}$ of gold nanoparticles, showed an increase of propidium iodide positive dead cell (Red colour) in both, Annexin-V FITC positive cell (green colour) (Figure 8A), and cells which are both propidium iodide and Annexin VFITC positive (scatted greens orange); this indicates that treatment of gold nanoparticle in HepG2 cells (Figure 8B), positive A549 cells (Fig. 8C) and treated A549 cancer cells (Figure 8D) caused apoptosis. The staining confirmed the efficiency of biofunctionalized gold nanoparticles causing apoptosis. Investigation of apoptosis via Annexin $\mathrm{V}$ staining has also been reported, e.g., for $\mathrm{TiO}_{2}$ nanoparticles [33] and fullerenes [34]. The change in nuclear morphology was determined by staining with the DNA-binding Hoechst dye in the presence of the biofunctionalized gold nanoparticle. Gold nanoparticle treated HepG2 and A549 cells were stained by Hoechst and morphological changes were immediately observed under a confocal fluorescence microscope (CFM). Untreated control cells exhibited blue-nuclei (Figure 9A), whereas, HepG2 cell treated with $82.91 \mathrm{nM}$ (Figure 9B) and A549 cell treated with $144.16 \mathrm{nM}$ of gold nanoparticles exhibited blue- nucleus with fluorescence, showing condensed chromatin as bright blue areas when compared to control cells (Figure 9C and 9D). Gold nanoparticle induced apoptotic morphological changes on HepG2 and A549 cells were observed after 24h treatment. The cells were then stained by acridine orange $(\mathrm{AO})$ and the change in morphologies were immediately observed using confocal microscopy. Untreated control cells exhibited bright green-nuclei fluorescence (Figure 10A), whereas, HepG2 cell treated with $82.91 \mathrm{nM}$ (Figure 10B) and A549 cell treated with $144.16 \mathrm{nM}$ of gold nanoparticle exhibited orange- nucleus fluorescence (Figure 10C) when compared to control lung cancer cell (Figure 10D). It showed condensation of chromatin and DNA fragmentation as dense orange areas; this dense orange area indicated mitochondrial depolarization. The irregular size was due to loss of cellular volume associated with cytoskeletal breakdown and plasma membrane blebbing. These changes are the hallmark of cell undergoing apoptosis [35]. Assessments of membrane integrity with vital dye, such as trypan blue are nonspecific to determine the mode of cell death such as apoptotic cells unless morphological characteristics can be analyzed with the dyes [36]. Therefore, here Acridine orange (AO) a cell-permeable DNA-binding dye was used to analyze the morphological changes that occurred in the DNA. The results of this staining revealed that the gold nanoparticle induced the nuclear condensation and cell fragmentation.

\section{Conclusion}

The present study explores the potential antitumor activity of biologically synthesized AuNPs in a lung and liver tumor system in vitro by activation of molecular mechanism of cell death. The drug delivery systems are mainly developed according to their ability to differentiate 
Citation: Singh M, Kumar M, Manikandan S, Chandrasekaran N, Mukherjee A, et al. (2014) Drug Delivery System for Controlled Cancer Therapy Using Physico-Chemically Stabilized Bioconjugated Gold Nanoparticles Synthesized from Marine Macroalgae, Padina Gymnospora. J Nanomed Nanotechol S5:009. doi:10.4172/2157-7439.S5-009
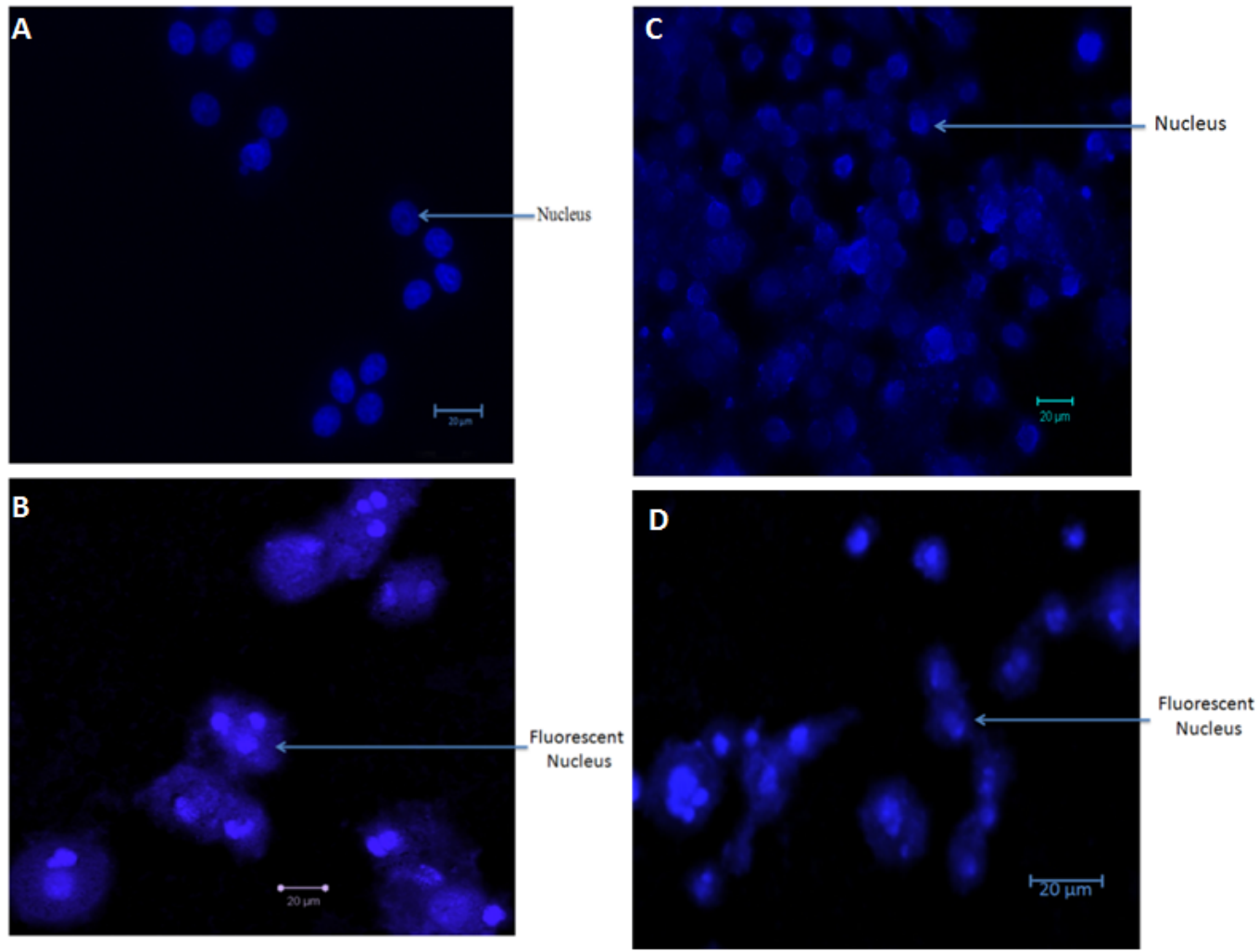

Figure 9: CFM -Hoechst staining: (A) Control HepG2 cell, (B) Gold nanoparticle induced chromatin condensation in HepG2 cancer cell (C) Control A549 cell, (D) Gold nanoparticle induced chromatin condensation in A549 cancer cells.
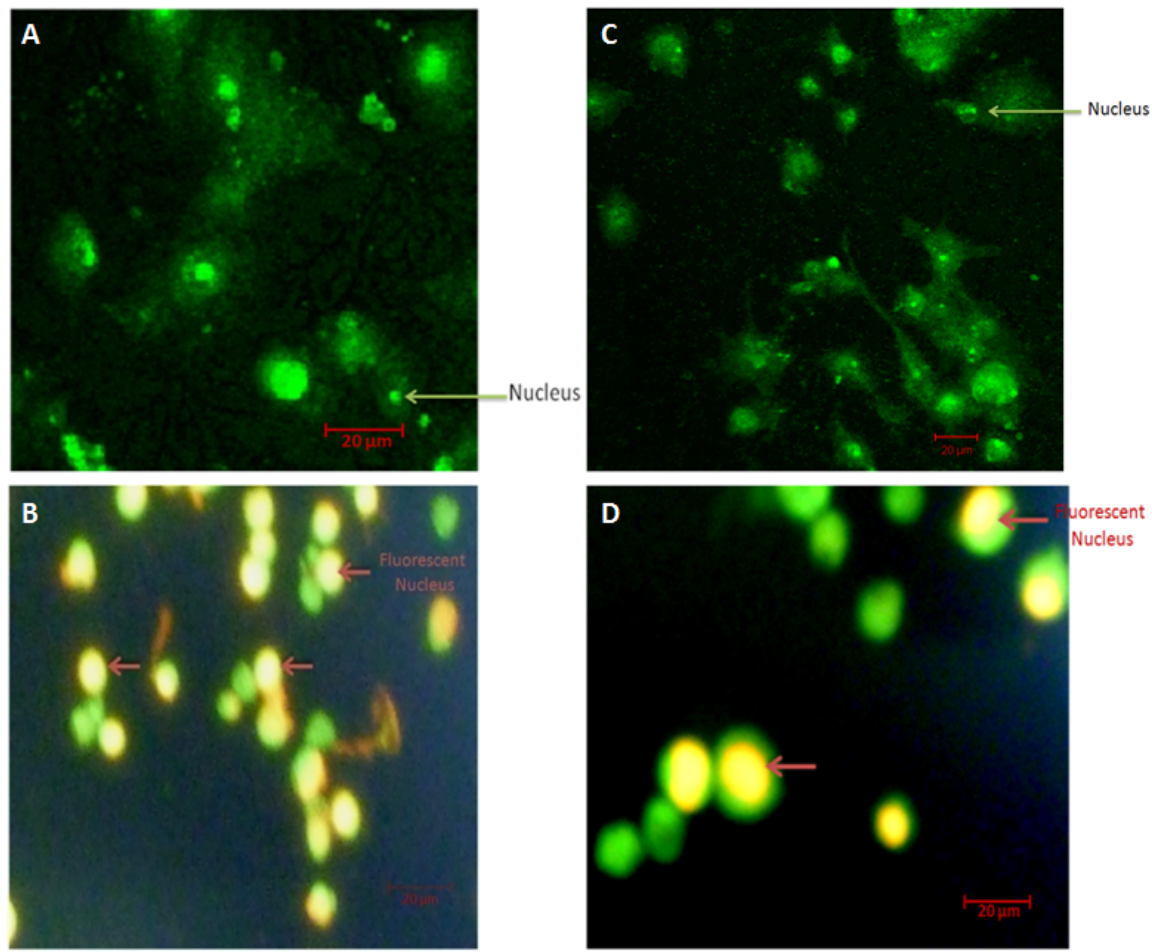

Figure 10: CFM - Acridine orange staining : (A) Control HepG2 cell (B) Gold nanoparticle induced chromatin condensation and DNA breakage in HepG2 cancer cell and (C) Control A549 cancer cells (D) Gold nanoparticle induced chromatin condensation and DNA breakage in A549 cancer cells 
Citation: Singh M, Kumar M, Manikandan S, Chandrasekaran N, Mukherjee A, et al. (2014) Drug Delivery System for Controlled Cancer Therapy Using Physico-Chemically Stabilized Bioconjugated Gold Nanoparticles Synthesized from Marine Macroalgae, Padina Gymnospora. J Nanomed Nanotechol S5:009. doi:10.4172/2157-7439.S5-009

between malignant and non-malignant cells, making them a promising alternative to existing drugs. This type of targeting efficiency of AuNPs can be accomplished in future therapies using peptide conjugation, which directly targets tumor cells without affecting normal cells. Thus, a study of the exact mechanism by which AuNPs inhibit signaling cascades responsible for the development and progression of the disease would be a tremendous breakthrough in the field of nanomedicine and make these agents an effective alternative in tumor and angiogenesisrelated diseases. Overall results obtained during this work have shown that the targeted gold nanoparticles have shown promising results in invitro studies and acted as a drug carrier. This exploration creates the new avenue to a new standard where the different carotenoids and alkaloidsfunctionalized gold nanoparticles can be a powerful weapon in the field of nanomedecine. Thus, the development of biosynthetic approach and biofunctionalized targeted gold nanoparticles as therapeutic agents will generate great interest in both academy and industry.

\section{Acknowledgment}

Author thanks the management of Madurai Kamaraj University and VIT University for their encouragement and support for providing necessary infrastructure to conduct the research. The authors wish to acknowledge Indian Council of Medical Research (ICMR) for their financial assistance for this project (Grant No. 45/2/2011-Nan/BMS). We are also thankful to (AIRF Laboratory) Jawaharlal Nehru University, New Delhi, India for HRTEM analysis.

\section{References}

1. Suriamoorthy P, Zhang X, Hao G, Joly AG, Singh S, et al. (2010) Folic acid$\mathrm{CdTe}$ quantum dot conjugates and their applications for cancer cell targeting. Cancer Nano 1: 19-28.

2. Parkin DM, Bray F, Ferlay J, Pisani $P(2001)$ Estimating the world cancer burden: Globocan 2000. Int J Cancer 94: 153-156.

3. Parveen S, Sahoo SK (2006) Nanomedicine: clinical applications of polyethylene glycol conjugated proteins and drugs. ClinPharmacokinet 45: 965-988.

4. Smith GL, Shih YC, Giordano SH, Smith BD, Buchholz TA (2010) A method to predict breast cancer stage using Medicare claims. EpidemiolPerspectInnov 7: 1

5. Nel A, Xia T, Mädler L, Li N (2006) Toxic potential of materials at the nanolevel. Science 311: 622-627.

6. Seigneuric R, Markey L, Nuyten DS, Dubernet C, Evelo CT, et al. (2010) From nanotechnology to nanomedicine: applications to cancer research. CurrMol Med 10: 640-652.

7. Thorek DL, Chen AK, Czupryna J, Tsourkas A (2006) Superparamagnetic iron oxide nanoparticle probes for molecular imaging. Ann Biomed Eng 34: 23-38.

8. Park JH, Kim JY, Chin BD, Kim YC, Kim JK, et al. (2004) White emission from polymer/quantum dot ternary nanocomposites by incomplete energy transfer. Nanotechnology 15: 1217-1220.

9. Huang X, Jain PK, El-Sayed IH, El-Sayed MA (2007) Gold nanoparticles: interesting optical properties and recent applications in cancer diagnostics and therapy. Nanomedicine (Lond) 2: 681-693.

10. El-Sayed IH, Huang X, El-Sayed MA (2006) Selective laser photo-therma therapy of epithelial carcinoma using anti-EGFR antibody conjugated gold nanoparticles. Cancer Lett 239: 129-135.

11. Abdelwahed W, Degobert G, Stainmesse S, Fessi H (2006) Freeze-drying of nanoparticles: formulation, process and storage considerations. Adv Drug Deliv Rev 58: 1688-1713.

12. Donaldson K, Aitken R, Tran L, Stone V, Duffin R, et al. (2006) Carbon nanotubes: a review of their properties in relation to pulmonary toxicology and workplace safety. ToxicolSci 92: 5-22.

13. Wyllie AH (1980) Glucocorticoid-induced thymocyte apoptosis is associated with endogenous endonuclease activation. Nature 284: 555-556.

14. O'Connor PM, Wassermann K, Sarang M, Magrath I, Bohr VA, et al. (1991) Relationship between DNA cross-links, cell cycle, and apoptosis in Burkitt's lymphoma cell lines differing in sensitivity to nitrogen mustard. Cancer Res 51 : $6550-6557$.
15. Koopman G, Reutelingsperger CP, Kuijten GA, Keehnen RM, Pals ST, et al. (1994) Annexin $V$ for flow cytometric detection of phosphatidylserine expression on B cells undergoing apoptosis. Blood 84: 1415-1420.

16. Durand RE (1982) Use of Hoechst 33342 for cell selection from multicell systems. J HistochemCytochem 30: 117-122.

17. Mirrett S (1982) Topics in clinical microbiology. American Journal of Infection Control 3: $250-252$

18. Chandran SP, Chaudhary M, Pasricha R, Ahmad A, Sastry M (2006) Synthesis of gold nanotriangles and silver nanoparticles using Aloe vera plant extract. BiotechnolProg 22: 577-583.

19. Kasthuri J, Kathiravan K, Rajendiran NJ (2009) Phyllanthin-assisted biosynthesis of silver and gold nanoparticles: a novel biological approach. The Journal of Nanoparticle Research 11: 1075-1085.

20. Shipway AN, Katz E, Willner I (2000) Nanoparticle arrays on surfaces for electronic, optical, and sensor applications. Chemphyschem 1: 18-52.

21. Song JY, Jang HK, Kim BS (2009) Biological synthesis of gold nanoparticles using Magnolia kobus and Diopyros kaki leaf extracts. Process Biochemistry 44: 1133-1138.

22. Shankar SS, Rai A, Ahmad A, Sastry M (2004) Rapid synthesis of Au, Ag, and bimetallic Au core-Ag shell nanoparticles using Neem (Azadirachtaindica) leaf broth. J Colloid Interface Sci 275: 496-502.

23. Singh $M$, Kalaivani $R$, Manikandan $S$, Sangeetha $N$, Kumaraguru AK (2012) Facile green synthesis of variable metallic gold nanoparticle using Padinagymnospora, a brown marine macroalga. Applied Nanoscience 2: 1-7.

24. El-Shahaby O, El-Zayat M, Salih E, El-Sherbiny IM, Reicha FM (2013) Evaluation of Antimicrobial Activity of Water Infusion Plant-Mediated Silver Nanoparticles. J Nanomed Nanotechol 4: 178

25. Lee S and Park H (2010) Anticancer activity of guava (Psidiumguajava) branch extracts against HT-29 human colon cancer cells. Journal of Medicinal Plants Research 4: 891-896.

26. Chen PC, Mwakwari SC, Oyelere AK (2008) Gold nanoparticles: From nanomedicine to nanosensing. NanotechnolSciAppl 1: 45-65.

27. Gobin AM, Lee MH, Halas NJ, James WD, Drezek RA, et al. (2007) Nearinfrared resonant nanoshells for combined optical imaging and phototherma cancer therapy. Nano Lett 7: 1929-1934.

28. Sperling RA, Rivera Gil P, Zhang F, Zanella M, Parak WJ (2008) Biological applications of gold nanoparticles. ChemSoc Rev 37: 1896-1908.

29. Giljohann DA, Seferos DS, Daniel WL, Massich MD, Patel PC, et al. (2010) Gold nanoparticles for biology and medicine. AngewChemInt Ed Engl 49: 32803294.

30. Gavrieli Y, Sherman Y, Ben-Sasson SA (1992) Identification of programmed cell death in situ via specific labeling of nuclear DNA fragmentation. J Cell Bio 119: 493-501.

31. Zhao ZQ, Nakamura M, Wang NP, Wilcox JN, Shearer S, et al. (2000) Reperfusion induces myocardial apoptotic cell death. Cardiovasc Res 45: 651 660

32. Oberhammer F, Wilson JW, Dive C, Morris ID, Hickman JA et al. (1993) Apoptotic death in epithelial cells: Cleavage of DNA to 300 and/or $50 \mathrm{~kb}$ fragments prior to or in the absence of internucleosomal fragmentation. The European Molecular Biology Organization Journal 12: 3679-3684

33. Aljandali A, Pollack H, Yeldandi A, Li Y, Weitzman SA, et al. (2001) Asbesto causes apoptosis in alveolar epithelial cells: role of iron-induced free radicals. J Lab Clin Med 137: 330-339.

34. Isakovic A, Markovic Z, Todorovic-Markovic B, Nikolic N, Vranjes-Djuric S, et al. (2006) Distinct cytotoxic mechanisms of pristine versus hydroxylated fullerene. ToxicolSci 91: 173-183.

35. Ciapetti G, Granchi D, Savarino L, Cenni E, Magrini E, et al. (2002) In vitro testing of the potential for orthopedic bone cements to cause apoptosis of osteoblast-like cells. Biomaterials 23: 617-627.

36. Allen RT, Hunter WJ 3rd, Agrawal DK (1997) Morphological and biochemical characterization and analysis of apoptosis. J PharmacolToxicol Methods 37 215-228. 